\title{
Клинический случай персонализации терапии варфарином: фармакогенетическое тестирование и межлекарственное взаимодействие
}

\author{
Георгиева К. С. ${ }^{2}$, Павлова С. И.', Богданова С. М.', Бурашникова И. С. ${ }^{2}$, Максимов М. Л.² \\ 1 - ФГБОУ ВО «Чувашский государственный университет им. И. Н. Ульянова», Россия, Чебоксары \\ - Казанская государственная медицинская академия - филиал ФГБОУ ДПО РМАНПО \\ Минздрава России, Россия, Казань
}

\begin{abstract}
Ключевые слова: персонализация терапии; варфарин; фармакогенетическое тестирование; межлекарственное взаимодействие

Для цитирования:

Георгиева К.С., Павлова С.И., Богданова С.М., Бурашникова И.С., Максимов М.Л. Клинический случай персонализации терапии варфарином: фармакогенетическое тестирование и межлекарственное взаимодействие // Фармакогенетика и фармакогеномика. 2020;(2):30-31. (In Russ). DOI: 10.37489/2588-0527-2020-2-30-31
\end{abstract}

Первичная и вторичная профилактика тромбоэмболических осложнений у пациентов с постоянной формой фибрилляции предсердий является актуальной, в связи с увеличением риска ишемического инсульта в $3-5$ раз, а смертности в $1,5-2$ раза [1]. Препаратами выбора остаются пероральные антикоагулянты непрямого действия, а также новые оральные антикоагулянты. Значительная «доказательная база» эффективности накоплена для варфарина. Несмотря на существующие схемы подбора доз варфарина под контролем международного нормализованного отношения (МНО), значительными остаются риски кровотечений, которые развиваются почти в $26 \%$ случаев, среди которых «большие», в том числе фатальные - почти в 4,2 \% [2, 3]. Риск кровотечений соотносится с уровнем МНО и увеличивается в 1,37 раза на каждые 0,5 единицы его повышения.

В настоящее время доказано, что дозирование варфарина зависит от генетических особенностей пациента, а именно от носительства полиморфизмов, задействованных в его фармакокинетике и фармакодинамике. Основным ферментом биотрансформации варфарина в печени является изофермент цитохрома Р-450 СYР2С9. Носительство аллельных вариантов CYP2C9*2 (rs 1799853) и CYP2C9*3 (rs 1057910) гена CYP2C9 приводит к снижению скорости биотрансформации варфарина и повышению риска геморрагических осложнений. Ген VKORC1 кодирует молекулу-мишень для варфарина - субъединицу 1 витамин К эпоксидредуктазного комплекса [2, 4]. Носительство полиморфизма G3673A (rs9923231) гена VKORC1 ассоциировано с повышен- ным риском кровотечений при применении варфарина $[1,2,5]$. Кроме того, в процессе свертывания крови принимает участие фермент $\gamma$-глутарил карбоксилаза (GGCX), осуществляющий посттрансляционное $\gamma$-карбоксилирование глутамат-содержащих белков системы свертывания крови - II (F2), VII (F7), IX (F9), X (F10) факторов. Показано, что некоторые полиморфизмы гена $G G C X$, например, rs12714145 $8016 G>A$, rs11676382 2084+45 $G>C$ accoциированы с более низкими подобранными дозами варфарина. Также генотип $C C$ по полиморфному маркеру V433M CYP4F2 требует подбора более низких доз варфарина по сравнению с пациентами с генотипами $C T$ и $T T[2,5]$. Дозирование варфарина с учётом результатов генотипирования по данным полиморфизмам может повысить эффективность и безопасность антикоагулянтной терапии. Также существуют различные алгоритмы расчёта дозы варфарина с учётом генотипа, а также принимаемой сопутствующей фармакотерапии, наиболее известным из которых является WarfarinDosing.

Описание пациента. Пациентка В., русская, 54 года. Основной диагноз: ИБС: Нарушение ритма по типу постоянной формы фибрилляции предсердий. Стенокардия напряжения, ФК 2. Конкурирующий диагноз: Врождённый порок сердца. Двустворчатый аортальный клапан: Комбинированный аортальный порок. СДСТ: Врождённая недостаточность митрального клапана 3-й степени. Наблюдалась в терапевтическом отделении г. Чебоксары. Тип вмешательства. Принимала в качестве антикоагулянта препарат варфарин внутрь по 2,5 мг - 2 таблетки в 18:00 (5 мг в сутки). 
Показание к персонализации: на фоне назначенной терапии у пациентки отмечалась избыточная степень коагуляции, увеличение МНО до 8, в связи с чем было рекомендовано проведение фармакогенетического тестирования с целью подбора дозы варфарина.

Тип персонализации: фармакогенетическое тестирование методом ПЦР в режиме реального времени. Определяли полиморфизмы: СYP2C9 *2, *3, *5, *6, rs9923231 гена VKORC1 (маркер G1639A), rs2108622 гена CYP4F2 (маркер G1279A), rs11676382 гена $G G C X$ (маркер 2084+45 $G>C$ ). Было выявлено гетерозиготное носительство полиморфизмов СYР2C9*2 (генотип $\mathrm{AC}$ ) и $2084+45 G<C$ гена $G G C X$ (генотип $C G$ ), а также гомозиготное носительство полиморфизма G1639A гена VKORC1 (генотип AA), что могло стать причиной гипокоагуляции при назначении варфарина в дозе 5 мг у данной пациентки.

Изменения после персонализации. С учётом результатов генотипирования, с помощью калькулятоpa WarfarinDosing была рассчитана доза варфарина, которая составила 1,75 мг/сут. Пациентка принимала варфарин в указанной дозе в течение двух месяцев с МНО в пределах 2,5-2,8.

Динамика. Через 2 месяца она была повторно госпитализирована в терапевтическое отделение с обширным внутренним кровотечением. Отмечалась выраженная анемия, гемоглобин при поступлении 55,0 г/л, МНО - 12. После тщательного сбора анамнеза было выяснено, что участковым терапевтом в связи с ОРВИ были назначены азитромицин в дозе
500 мг, флуконазол в дозе 150 мг, а также пациентка принимала ибупрофен в суточной дозе 600 мг в связи с гипертермией. Причиной развития геморрагического синдрома в данном случае явилось межлекарственное взаимодействие варфарина и препаратов, назначенных для лечения ОРВИ. В частности, отмечалось фармакокинетическое взаимодействие варфарина и ибупрофена на уровне связи с белками крови с вытеснением варфарина, и потенцирование антикоагулянтного эффекта на фоне одновременного применения азитромицина и варфарина, в связи со снижением биотрансформации пероральных антикоагулянтов под действием макролидов. Также причиной усиления антикоагулянтного действия варфарина можно считать угнетение активности изоферментов СҮР2C9, CYР3А4 под влиянием флуконазола. Пациентке было перелито две дозы свежезамороженной плазмы, одна доза эритроцитарной массы. В дальнейшем она была выписана домой с МНО 2,7. В связи с необходимостью постоянной антикоагулянтной терапии, была проведена беседа о важности лабораторного контроля, ведения дневника, коррекции дозы варфарина при изменениях диеты и сопутствующей фармакотерапии.

Выводы. В данном случае, несмотря на проведение генотипирования, развились осложнения в виде кровотечения, вызванные изменением сопутствующей фармакотерапии. При назначении варфарина необходимо учитывать множество факторов, включая возраст, пол, национальность, образ жизни, генетические особенности пациента, сопутствующую терапию и избегать полипрагмазии.

\section{Литература / References}

1. Гаврисюк Е.В., Сычев Д.А., Казаков Р.Е., Коссовская А.В., Маринин В.Ф. Опыт использования фармакогенетического тестирования для персонализации дозирования варфарина в поликлинических условиях // ТМЖ. - 2015. - T.59. - №1. - C.60-62. [Gavrisyuk EV, Sychev DA, Kazakov RE et al. Experience in the use of pharmacogenetic testing for personalizing warfarin dosing in outpatient conditions. TMJ. 2015;59(1):60-62. (In Russ).]

2. Сычев Д.А. Персонализированная антикоагулянтная терапия на основе результатов фармакогенетического тестирования. - СПб. Алкорбио; 2010. [Sychev DA. Personalizirovannaya antikoagulyantnaya terapiya na osnove rezul'tatov farmakogeneticheskogo testirovaniya. $\mathrm{SPb}$.: Alkorbio; 2010. (In Russ).]

3. Сычев Д.А., Шуев Г.Н., Торбенков Е.С., Адриянова М.А. Персонализированная медицина: взгляд клинического фармаколога // Consilium Medicum. - 2017. - T.19. №1. - C.61-68. [Sychev

DA, Shuev GN, Torbenkov ES, Adrijanova MA.Personalized medicine: clinical pharmacologist's opinion. Consilium Medicum. 2017;19(1):61-68. (In Russ).]

4. Румянцев Н.А., Сычёв Д.А., Кукес В.Г., и др. Опыт индивидуализации применения и дозирования пероральных антикоагулянтов в условиях функционирования центра персонализированной медицины // Казанский медицинский журнал. - 2015. - Т.96. - №6. C.1065-1068. [Rumyantsev NA, Sychev DA, Kukes VG. Experience of individualization of oral anticoagulants use and dosage in personalized medicine centre conditions. KMJ. 2015;96(6):1065-1068. (In Russ).]. DOI: $10.17750 /$ KMJ2015-1065

5. Bairova TA, Sambyalova AYu, Rychkova LV et al. Pharmacogenetic warfarin dosing algorithm in the Russian population. Acta Biomedica Scientifica. 2019;(3):40-44. 